\title{
LENGTH-WEIGHT AND LENGTH-LENGTH RELATIONS, AND RELATIVE CONDITION FACTOR OF RED LIONFISH, PTEROIS VOLITANS (ACTINOPTERYGII: SCORPAENIFORMES: SCORPAENIDAE), FROM TWO NATURAL PROTECTED AREAS IN THE MEXICAN CARIBBEAN
}

\author{
Miguel M. SABIDO-ITZÁ ${ }^{1 *}$, Alfonso AGUILAR-PERERA², and Alejandro MEDINA-QUEJ ${ }^{1}$ \\ ${ }^{1}$ Maestría en Manejo de Zona Costera, Instituto Tecnológico de Chetumal, Chetumal, Quintana Roo, México \\ ${ }^{2}$ Departamento de Biología Marina, Universidad Autónoma de Yucatán, Mérida, Yucatán, México
}

Sabido-Itzá M.M., Aguilar-Perera A., Medina-Quej A. 2016. Length-weight and length-length relations, and relative condition factor of red lionfish, Pterois volitans (Actinopterygii: Scorpaeniformes: Scorpaenidae), from two natural protected areas in the Mexican Caribbean. Acta Ichthyol. Piscat. 46 (4): 279-285.

Background. Biological invasions are often listed among the main threats to the ecosystem and are considered drivers of biodiversity loss. The Indo-Pacific lionfish, Pterois volitans (Linnaeus, 1758) (hereafter lionfish), invaded the Atlantic Ocean where it threatens the stability of the marine ecosystem. It would be crucial to know its biological characteristics to understand how environmental parameters could affect its growth. It is also important to continue the earlier efforts of management and control. In this study, we described the $L-W$ and $L-L$ relations and the relative condition factor of lionfish in two natural protected areas in the southern coast of Quintana Roo, Mexico.

Materials and methods. Lionfish were captured during 2012 and 2013 from the Reserva de la Biosfera Banco Chinchorro (RBBC) and the Parque Nacional Arrecifes de Xcalak (PNAX). The length-weight relation was calculated based on the equation $W=a \mathrm{TL}^{b}$. The relative condition factor was calculated through the relative weight.

Results. A total of 817 lionfish were caught in the frames of this study. In this number, there were 449 individuals from the RBBC $(282.1 \pm 62.1 \mathrm{~mm} \mathrm{TL})$ and 368 from the PNAX $(249.2 \pm 77.6 \mathrm{~mm} \mathrm{TL})$. The $L-W$ relation for lionfish from the RBBC was $W=0.0041 \mathrm{TL}^{3.258}$ and that for the PNAX was $W=0.0049 \mathrm{TL}^{3.191}$. There was a significant difference between these relations (ANCOVA, $F=3.91 ; P=0.0481$ ). The growth type was positive allometric. The $L-L$ relation was significant. The relative condition factor differed between areas only in 2013, but a high value was determined in 2012 .

Conclusions. The $L-W$ relations were different between locations (RBBC and PNAX) but no between years. The relative condition factor showed high values $(>100)$ for both locations which may imply that lionfish is in good shape, in the studied location, due to environmental factors providing good food supply and because of the lack of predators. These results may be useful as a baseline to document the population dynamics of lionfish in the region.

Keywords: $L-W$ relation, relative condition factor, Yucatan Peninsula, Banco Chinchorro, Xcalak

\section{INTRODUCTION}

The Indo-Pacific red lionfish, Pterois volitans (Linnaeus, 1758) (thereafter lionfish), invaded the eastern coast of the Atlantic Ocean, the Caribbean Sea, the Gulf of Mexico (Schofield 2010), and also the Brazilian coast (Ferreira et al. 2015). Lionfish represents a threat to the biodiversity and stability of the marine ecosystems due to its high voracity (Morris and Akins 2009) causing reduction in the abundance of native fish and invertebrates (Albins and Hixon 2008, Côté et al. 2013, Ballew et al. 2016). In Mexico, lionfish was detected in the late 2009, both in the Mexican Caribbean and southern Gulf of
Mexico (Aguilar-Perera and Tuz-Sulub 2010, Sabido-Itzá et al. 2012), where now it is considered as established (López-Gómez et al. 2014, Sabido-Itzá et al. 2016). Thus, it is imperative to know further its biology to understand the ecological effects due to its invasion in the marine ecosystem of the region.

The length-weight relation $(L-W)$ is an important tool (Le Cren 1951, Giacalone et al. 2010) to estimate attributes of the population, such as:

- The fish weight based on length;

- Fish weight based on growth;

- Biomass; and

* Correspondence: Miguel M. Sabido-Itzá, Instituto Tecnológico de Chetumal, Maestría en Manejo de Zona Costera, Avenida Insurgentes \#330, col. David Gustavo Gutiérrez, Chetumal, Quintana Roo, México, C.P. 77013, phone: +52 983-106-9565, e-mail: (MMSI) mateosabido@gmail.com, (AAP) alfaguilar@gmail.com, (AMQ) lexobu@gmail.com. 
- The condition factor (Petrakis and Stergiou 1995, Gonçalves et al. 1997, Kimmerer et al. 2005, Froese 2006, Froese et al. 2011).

Length-length $(L-L)$ relations are used for conversion between lengths (Klassen et al. 2014). The $L-W$ relation may differ between individuals of the same species in regions, seasons and sex (Okgerman 2005, Froese 2006). While it is important to know this relation for either native species or species under population threat (Vega-Cendejas et al. 2012, Hossain et al. 2014), when an invasive species is established it is crucial to document this relation in order to detect temporal and spatial fluctuations of the population in the invaded ecosystem.

This work aimed to calculate the $L-W$ and $L-L$ relations, and the relative condition factor, of lionfish in two natural protected areas off the southern coast of Quintana Roo, Mexico.

\section{MATERIALS AND METHODS}

Study area. The Reserva de la Biosfera Banco Chinchorro (RBBC) $\left(18^{\circ} 47^{\prime}-18^{\circ} 23^{\prime} \mathrm{N}, 87^{\circ} 14^{\prime}-87^{\circ} 27^{\prime} \mathrm{W}\right)$ is a coral reef complex (144 $360 \mathrm{ha}$ ) located at $30.8 \mathrm{~km}$ off the coast of Quintana Roo (Carricart-Ganivet and BeltránTorres 1998). The Parque Nacional Arrecifes de Xcalak (PNAX) $\left(18^{\circ} 30^{\prime}-18^{\circ} 11^{\prime} \mathrm{N}, 87^{\circ} 43^{\prime}-87^{\circ} 50^{\prime} \mathrm{W}\right)$ (17 949 ha) is located along the southern coast of Quintana Roo, close to Belize (Anonymous 2004) (Fig. 1).

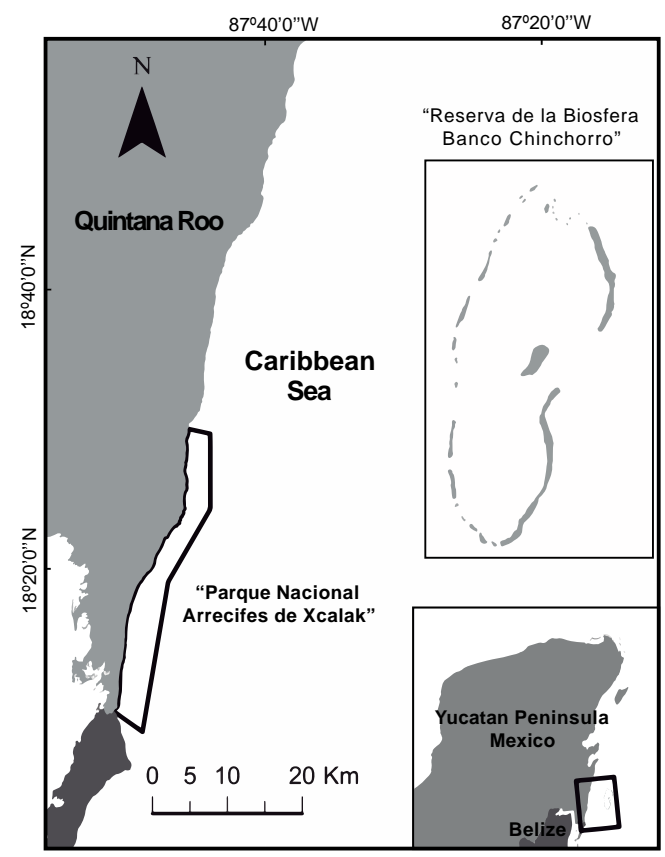

Fig 1. Location of the Natural Protected Areas, Parque Nacional Arrecifes de Xcalak and Reserva de la Biosfera Banco Chinchorro, on the southern Quintana Roo, México

Fieldwork. Lionfish were collected by local fishermen and divers with spear guns from February through November 2012 and from January through May 2013. At laboratory, each fish was taxonomically identified to species, according to Schultz (1986), measured in total length (TL) and standard length (SL) in mm, and weighed in $\mathrm{g}$ to total and eviscerated weight using an electronic scale.

Data analysis. Size-frequency distributions were built based on intervals of $20 \mathrm{~mm}$ TL to compare the size distribution between localities using $D_{\max }$ from Kolmogorov-Smirnov (K-S):

$$
D_{\max }=\max \left(\left|F_{1}(x)-F_{2}(x)\right|\right)
$$

where $D_{\max }$ is the maximum cumulative difference from samples, $F_{1}$ is the proportion of values lesser or equal to $x$ in the first distribution, and $F_{2}$ is the proportion of values less or equal to $x$ in the second distribution.

The $L-W$ relation was calculated based on the equation

$$
W=a \mathrm{TL}^{b}
$$

where $W$ is the total weight of fish, $L$ is the total length in $\mathrm{mm}, a$ is the intercept, and $b$ is the regression coefficient (slope) (Le Cren 1951, Froese 2006). The coefficients $a$ and $b$ were estimated by a lineal regression on logarithms:

$$
\ln (W)=\ln (a)+b \ln (L)
$$

The $95 \%$ confident intervals of $a$ and $b$, and the coefficient of determination $\left(r^{2}\right)$ were also calculated. Outliers were addressed based on Froese (2006). The $b$ value of each relation was evaluated with a Student's $t$-test to determine the difference to isometry $(b=3)$. The relation TL-SL was also estimated through a lineal regression. The slopes of the $L-W$ relation were compared between years and area through analysis of covariance (ANCOVA). In order to estimate the relative condition factor between space and time, the relative weight $\left(W_{\mathrm{r}}\right)$ was used according to Froese (2006) as:

$$
W_{\mathrm{r}}=100 \frac{W}{a_{\mathrm{m}} L^{b_{\mathrm{m}}}}
$$

where $W_{\mathrm{r}}$ is the relative weight, $W$ and $L$ are the weight and length of each fish, $a_{\mathrm{m}}$ and $b_{\mathrm{m}}$ are the mean values of $a$ and $b$ from the $L-W$ relation of each location. The Student's $t$-test was used to compare $W_{\mathrm{r}}$ between locations each year.

\section{RESULTS}

A total of 817 lionfish was captured, of which 449 were from the RBBC and 368 from the PNAX. For the $\mathrm{RBBC}$, the fish length ranged between 100 and $395 \mathrm{~mm}$ TL $(282.1 \pm 62.1)$ and weight-between 9 and $845.7 \mathrm{~g}$ $(363.9 \pm 217.2)$, while for the PNAX the corresponding values were between 60 and $380 \mathrm{~mm}$ TL $(249.2 \pm 77.6)$ and 3 and $804 \mathrm{~g}(277.3 \pm 198.1)$, respectively. The size distribution of the fish from RBBC showed a main modal group between 260 and $3340 \mathrm{~mm}$ TL, while that from the PNAX showed two peaks where the main was 240 and $280 \mathrm{~mm}$ and a second one reached 80 to $120 \mathrm{~mm}$ TL. There were significant differences between size distributions from 
the RBBC showing larger sizes compared to those from the PNAX (K-S; $D_{\text {max }}=0.18, P<0.01$ ) (Fig. 2).

$L-W$ relations per area and year were both significant $(P$ $<0.01$ ) with $r^{2}$ ranging between 0.95 and 0.98 (Table 1). The coefficient $b$ was 3.25 in 2012 and 3.16 in 2013 for the PNAX and 3.27 and 3.30 for the RBBC, respectively (Table 1). The coefficient $b$ in all relations was significantly different to isometry ( $t$-test, $P<0.01$ ); thus, the growth of lionfish represents positive allometry. There were significant differences of the $L-W$ relation between $\mathrm{RBBC}$ and

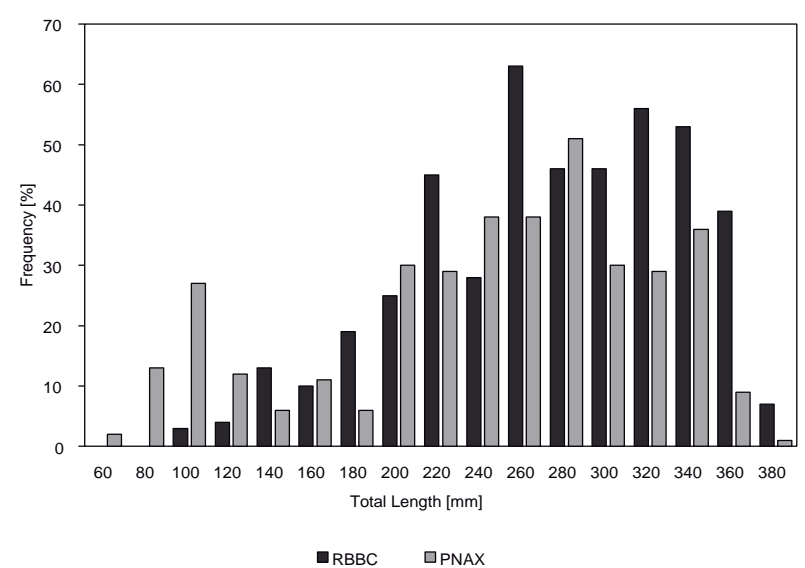

Fig. 2. Length frequency of lionfish, Pterois volitans, in the Reserva de la Biosfera Banco Chinchorro (RBBC, $N$ $=449$ ) and the Parque Nacional Arrecifes de Xcalak (PNAX, $N=368$ ) from the Mexican Caribbean
PNAX (ANCOVA: $F=3.91, P<0.05$ ) (Fig. 3), but there were no differences between years (2012-2013) per location (RBBC: $F=0.18, P>0.05$; PNAX: $F=3.53, P>0.05$ ). The $L-L$ relation was significant $(F=29440.08, P<0.01)$ with $r^{2}=0.99$ but showed no difference between areas (ANCOVA: $F=3.83, P>0.05$ ) (Table 2).

The relative condition factor for lionfish in the RBBC ranged between $149.1 \pm 19.4$ in 2012 and $136.9 \pm 16.9$ in 2013 ( $t$-test $=6.9, P<0.01)$, while in the PNAX ranged

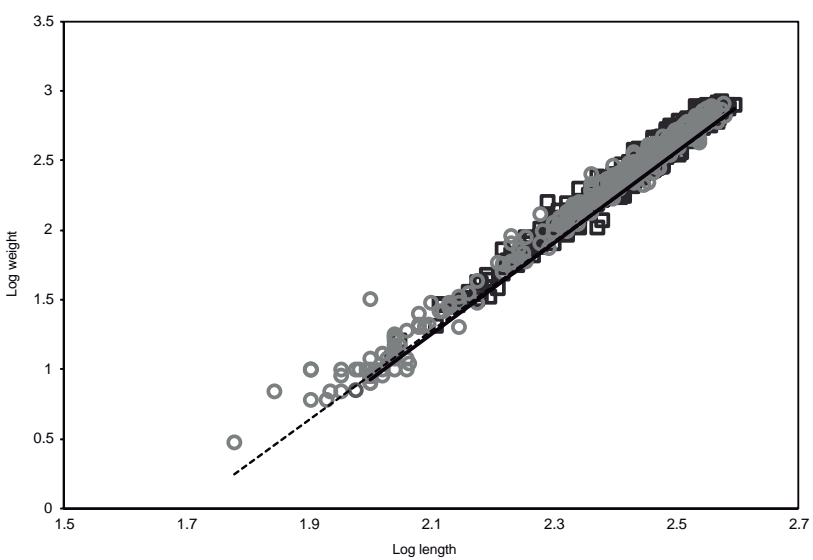

Fig. 3. Relation between Log length and log weight of lionfish, Pterois volitans, in two Natural Protected Areas: Reserva de la Biosfera Banco Chinchorro (RBBC) (square grey) and Parque Nacional Arrecifes de Xcalak (PNAX) (circle grey); RBBC: solid line; PNAX: dashed line

Table 1

Lineal relations $(y=a+b x)$ between total length and weight of lionfish, Pterois volitans, in two natural protected areas in the Mexican Caribbean

\begin{tabular}{|c|c|c|c|c|c|c|c|c|c|c|c|c|}
\hline \multirow{2}{*}{ Location } & \multirow{2}{*}{ Year } & \multirow{2}{*}{$n$} & \multicolumn{2}{|c|}{$\mathrm{TL}[\mathrm{mm}]$} & \multicolumn{2}{|c|}{ Weight $[\mathrm{g}]$} & & \multirow{2}{*}{$b$} & \multirow{2}{*}{ CL 95\% (a) } & \multirow{2}{*}{ CL 95\% (b) } & \multirow{2}{*}{$r^{2}$} & \multirow{2}{*}{$W_{\mathrm{r}}$} \\
\hline & & & Mean & Range & Mean & Range & & & & & & \\
\hline \multirow[t]{2}{*}{ RBBC } & 2012 & 324 & 278.6 & $10-386$ & 366.7 & $9-845.7$ & 0.0040 & 3.27 & $0.004-0.005$ & $3.22-3.32$ & 0.98 & 149.12 \\
\hline & 2013 & 125 & 291.2 & $157-395$ & 356.8 & $33-800.6$ & 0.0036 & 3.30 & $0.003-0.005$ & $3.17-3.42$ & 0.95 & 136.99 \\
\hline \multirow[t]{2}{*}{ PNAX } & 2012 & 149 & 269.0 & $60-380$ & 319.8 & $3-740$ & 0.0041 & 3.25 & $0.003-0.005$ & $3.17-3.33$ & 0.97 & 147.14 \\
\hline & 2013 & 219 & 235.8 & $70-378$ & 248.5 & $6-804$ & 0.0052 & 3.16 & $0.005-0.006$ & $3.11-3.21$ & 0.98 & 145.50 \\
\hline $\mathrm{RBBC}$ & $\begin{array}{l}2012+ \\
2013\end{array}$ & 449 & 282.1 & $100-395$ & 363.9 & $9-845.7$ & 0.0041 & 3.25 & $0.004-0.005$ & $3.20-3.30$ & 0.97 & 145.74 \\
\hline PNAX & $\begin{array}{l}2012+ \\
2013\end{array}$ & 368 & 249.2 & $60-380$ & 277.4 & $3-804$ & 0.0049 & 3.19 & $0.004-0.005$ & $3.14-3.23$ & 0.98 & 146.18 \\
\hline
\end{tabular}

RBBC $=$ Reserva de la Biosfera Banco Chinchorro, PNAX $=$ Parque Nacional Arrecifes de Xcalak, $n=$ number of fish, TL $=$ total length, $a=$ intercept, $b=$ slope, $\mathrm{CL}=$ confidence limit, $r^{2}=$ coefficient of determination, $W_{\mathrm{r}}=$ relative condition factor.

Table 2

Lineal relations $(y=a+b x)$ between total and standard lengths of lionfish, Pterois volitans, in two natural protected areas in the Mexican Caribbean

\begin{tabular}{ccccccc}
\hline Relation & Location & $a$ & $b$ & CL 95\% $(a)$ & CL 95\% $(b)$ & $r^{2}$ \\
\hline TL-SL & RBBC & -5.27 & 0.78 & $-7.74-2.80$ & $0.77-0.78$ & 0.98 \\
& PNAX & -3.02 & 0.77 & $-4.69-1.35$ & $0.76-0.77$ & 0.99 \\
SL-TL & RBBC & 10.53 & 1.26 & $7.48-13.58$ & $1.25-1.27$ & 0.98 \\
& PNAX & 5.58 & 1.29 & $3.45-7.70$ & $1.28-1.30$ & 0.99 \\
\hline
\end{tabular}

$\mathrm{RBBC}=$ Reserva de la Biosfera Banco Chinchorro, $\mathrm{PNAX}=$ Parque Nacional Arrecifes de Xcalak, $\mathrm{TL}=$ total length, $\mathrm{SL}=$ standard length, $a=$ intercept,$b=$ slope, $\mathrm{CL}=$ confidence limit, $r^{2}=$ coefficient of determination. 
between $147.1 \pm 21.9$ and $145.5 \pm 17.23$, respectively $(t$-test $=0.13, P>0.05)($ Table 1$) . W_{\mathrm{r}}$ showed a significant difference between areas in 2013 ( $t$-test $=-4.4, P<0.01$ ), but no difference in 2012 ( $t$-test $=1.4, P>0.05)$.

\section{DISCUSSION}

Size distributions of lionfish for both locations (RBBC and PNAX) mainly corresponded to reproductive capable adults (>189 mm TL) (Gardner et al. 2015). However, in the PNAX there was a modal group showing sizes representing juveniles (60-120 mm TL). Thus, it is probable that PNAX is a very important place for lionfish recruitment (VásquezYeomans et al. 2011). In the PNAX, there was a change in modal groups into larger size classes from $80-160 \mathrm{~mm}$ TL in 2009-2011 (Sabido-Itzá et al. 2016) to 240-280 mm in 2012-2013. This may imply that lionfish population is experiencing a growth trend (Côté and Maljković 2010, Pusack et al. 2016).

The size of the largest lionfish collected in the Mexican Caribbean, specifically in the RBBC (395 mm TL), was relatively similar to that collected in the southern Gulf of Mexico (389 mm TL, Aguilar et al. 2013) and to that in the Cayman Islands (391 mm TL, Edwards et al. 2014). However, the largest lionfish size captured in the western Atlantic was $477 \mathrm{~mm}$ TL for Islamorada, Florida.

The $L-W$ relations of lionfish from the Mexican Caribbean are described herewith for the first time. These relations explain an allometric growth type for lionfish with some slight differences. These differences may be due to environmental factors in a given geographic location, reef health, and habitat type (Díaz-Pérez et al. 2016), but also to biotic factors such as differences in the native community and availability of potential prey (GonzalezSalas et al. 2003, García-Salgado et al. 2006). In general, the vast majority of $b$ coefficients calculated for lionfish in different geographic areas show values greater than 3 (positive allometry), and only in two cases the coefficient $b$ was lower than 3 (Table 3 ).

The relative condition factor for lionfish from the Mexican Caribbean differed between areas only in 2013, but a high value was determined in 2012 . Values of relative condition factor lower than 100 indicate that fish is under low availability of food resources and high abundance of predators, while higher values indicate high abundance of prey and low predation (Froese 2006, Rypel and Richter 2008). In this case, lionfish from Mexican Caribbean with values higher than 100 imply a well-being of fish in both areas. This latter indicates that lionfish show a high rate of prey consumption in combination with a lack of predation for native fishes (groupers and snappers) for its possible biological control (Côté and Maljković 2010, Green et al. 2011, Hackerott et al. 2013).

On its native reef, lionfish is relatively smaller compared to that on invaded reefs (Darling et al. 2011). Consequently, the invaded environment, in the Mexican Caribbean, is favourable for its growth. Our results suggest that the PNAX and the RBBC could offer a suitable habitat for the establishment of lionfish despite some of their population attributes (e.g., size distribution, condition factor and length-weight relation) may differ at close geographic proximity. This study provides suitable information useful as a baseline to delineate population dynamic models to assess the progression of the invasion of lionfish in the Mexican Caribbean. This latter is of particular importance for management practices, based on culling, to face the invasion. In fact, so far the RBBC and the PNAX are under culling program for lionfish with the collaboration of voluntary fishermen. Such programs are expected to foster conservation efforts of these natural protected areas (Sabido-Itzá et al. 2016). In addition to continuing the culling program, it is recommended to conduct surveys to estimate lionfish density. Also studies

Table 3

Mean total length and coefficients of the $\mathrm{L}-\mathrm{W}$ relations estimated for lionfish, Pterois volitans, in Western Atlantic, Caribbean Sea, and Gulf of Mexico

\begin{tabular}{|c|c|c|c|c|c|c|}
\hline \multirow{2}{*}{ Locality } & \multicolumn{2}{|c|}{$\mathrm{TL}[\mathrm{cm}]$} & \multirow{2}{*}{$a$} & \multirow{2}{*}{$b$} & \multirow{2}{*}{$r^{2}$} & \multirow{2}{*}{ Source } \\
\hline & Mean \pm SD & Range & & & & \\
\hline North Carolina, USA & - & - & 0.0000289 & 2.89 & $\mathrm{Na}$ & Barbour et al. 2011 \\
\hline New Providence, Bahamas & 23 & $17-29$ & 0.00497 & 3.29 & $\mathrm{Na}$ & Darling et al. 2011 \\
\hline Northern Gulf of Mexico & - & $12.6-38.5$ & 0.0028 & 3.43 & 0.99 & Fogg et al. 2013 \\
\hline Puerto Rico & $16.3 \pm 6.1$ & $5.7-34.9$ & 0.08 & 3.11 & 0.95 & Toledo-Hernández et al. 2014 \\
\hline Northern Gulf of Mexico & 24.29 & $6.7-37.7$ & 0.00000207 & 3.34 & 0.98 & Dahl and Patterson 2014 \\
\hline Little Cayman & - & $2.7-39.1$ & 0.000003 & 3.24 & 0.97 & Edwards et al. 2014 \\
\hline Costa Rica & $18.7 \pm 5.7$ & - & 0.0235 & 2.81 & $\mathrm{Na}$ & Sandel et al. 2015 \\
\hline Alacranes reef, Mexico & - & $9-35$ & 0.104 & 3.30 & 0.98 & Perera-Chan and Aguilar-Perera 2014 \\
\hline Alacranes reef, Mexico & - & $9-38.9$ & 0.011 & 3.33 & 0.97 & Rodríguez-Cortés et al. 2015 \\
\hline Cuba & $\sim 25$ & - & 0.012 & 3.01 & $\mathrm{Na}$ & Cobián-Rojas et al. 2016 \\
\hline Xcalak, Mexico & $16.4 \pm 7.2$ & $2.5-37.5$ & 0.0079 & 3.18 & 0.99 & Sabido-Itzá et al. 2016 \\
\hline Banco Chinchorro, Mexico & 28.2 & $10-39.5$ & 0.0041 & 3.25 & 0.97 & This study \\
\hline Xcalak, Mexico & 24.9 & $6.0-38.0$ & 0.0049 & 3.19 & 0.98 & This study \\
\hline
\end{tabular}

$\mathrm{TL}=$ total length, $\mathrm{TL}$ values are mean \pm standard deviation (where available) and range, $a=$ intercept, $b=$ slope, $r^{2}=$ coefficient of determination. 
on stomach content analysis are desirable in order to determine the possible impact of the lionfish invasion on the native fauna of the region.

\section{ACKNOWLEGMENTS}

The Comisión Nacional de Áreas Naturales Protegidas (CONANP), with the help of the personnel of the natural protected areas Reserva de la Biosfera Banco Chinchorro and Parque Nacional Arrecifes de Xcalak, provided logistic and financial support. We thank local fishermen who actively participated in lionfish removals from coral reefs. We thank Irving Chávez for helping in editing figures.

\section{REFERENCES}

Aguilar-Perera A., Perera-Chan L., Quijano-Puerto L. 2013. Record body size for the red lionfish, Pterois volitans (Scorpaeniformes), in the southern Gulf of Mexico. Gulf and Caribbean Research 25 (1): 121123.

DOI: $10.18785 /$ gcr. 2501.10

Aguilar-Perera A., Tuz-Sulub A. 2010. Non-native, invasive red lionfish (Pterois volitans [Linnaeus, 1758]: Scorpaenidae), is first recorded in the southern Gulf of Mexico, off the northern Yucatan Peninsula, Mexico. Aquatic Invasions 5 (Suppl. 1): S9-12.

DOI: 10.3391/ai.2010.5.S1.003

Albins M.A., Hixon M.A. 2008. Invasive Indo-Pacific lionfish Pterois volitans reduce recruitment of Atlantic coral-reef fishes. Marine Ecology Progress Series 367: 233-238.

DOI: $10.3354 /$ meps 07620

Anonymous 2004. Programa de Manejo Parque Nacional Arrecifes de Xcalak. Diario Oficial de La Federación. Comision Nacional Areas Naturales Protegidas, Mexico City, Mexico.

BallewN.G.,BachelerN.M.,KellisonG.T.,SchuellerA.M. 2016. Invasive lionfish reduce native fish abundance on a regional scale. Scientific Reports 6: 32169. DOI: $10.1038 /$ srep32169

Barbour A.B., Allen M.S., Frazer T.K., Sherman K.D. 2011. Evaluating the potential efficacy of invasive lionfish (Pterois volitans) removals. PLoS ONE 6 (5): e19666.

DOI: 10.1371/journal.pone.0019666

Carricart-Ganivet J.P., Beltrán-Torres A.U. 1998. Chinchorro Bank: a threatened Mexican Caribbean atoll. Coral Reefs 17 (1): 36-36.

DOI: $10.1007 / \mathrm{s} 003380050091$

Cobián Rojas D., Chevalier Monteagudo P.P., Schmitter-Soto J., Corrada Wong R., Salvat Torres H., Cabrera Sansón E., García Rodríguez A.G., Fernández Osorio A., Espinosa Pantoja L., Cabrera Guerra D., Pantoja Echevaria L.M., Caballero Aragón H., Perera Valderrama S. 2016. Density, size, biomass, and diet of lionfish in Guanahacabibes National Park, western Cuba. Aquatic Biology 24 (3): 219-226.

DOI: $10.3354 / \mathrm{ab} 00651$
Côté I.M., Green S.J., Hixon M.A. 2013. Predatory fish invaders: Insights from Indo-Pacific lionfish in the western Atlantic and Caribbean. Biological Conservation 164: 50-61.

DOI: $10.1016 /$ j.biocon.2013.04.014

Côté I.M., Maljković A. 2010. Predation rates of IndoPacific lionfish on Bahamian coral reefs. Marine Ecology Progress Series 404: 219-225.

DOI: $10.3354 / \mathrm{meps} 08458$

Dahl K.A., Patterson W.F. III 2014. Habitat-specific density and diet of rapidly expanding invasive red lionfish, Pterois volitans, populations in the Northern Gulf of Mexico. PLoS ONE 9 (8): e105852.

DOI: $10.1371 /$ journal.pone.0105852

Darling E.S., Green S.J., O’Leary J.K., Côté I.M. 2011. Indo-Pacific lionfish are larger and more abundant on invaded reefs: A comparison of Kenyan and Bahamian lionfish populations. Biological Invasions 13 (9): 2045-2051.

DOI: $10.1007 / \mathrm{s} 10530-011-0020-0$

Díaz-Pérez L., Rodríguez-Zaragoza F.A., Ortiz M., Cupul-Magaña A.L., Carriquiry J.D., Rios-Jara E., Rodríguez-Troncoso A.P., García-Rivas M.C. 2016. Coral reef indices versus the biological, ecological and functional diversity of fish and coral assemblages in the Caribbean Sea. PLoS ONE 11 (8): e0161812.

DOI: $10.1371 /$ journal.pone.0161812

Edwards M.A., Frazer T.K., Jacoby C.A. 2014. Age and growth of invasive lionfish (Pterois spp.) in the Caribbean Sea, with implications for management. Bulletin of Marine Science 90 (4): 953-966.

DOI: $10.5343 / \mathrm{bms} .2014 .1022$

Ferreira C.E.L., Luiz O.J., Floeter S.R., Lucena M.B., Barbosa M.C., Rocha C.R., Rocha L.A. 2015. First record of invasive lionfish (Pterois volitans) for the Brazilian Coast. PLoS ONE 10 (4): e0123002.

DOI: 10.1371 /journal.pone.0123002

Fogg A.Q., Hoffmayer E.R., Driggers W.B.D. III, Campbell M.D., Pellegrin G.J., Stein W. 2013. Distribution and length frequency of invasive lionfish (Pterois sp.) in the northern Gulf of Mexico. Gulf and Caribbean Research 25 (1): 111-115.

DOI: $10.18785 /$ gcr. 2501.08

Froese R. 2006. Cube law, condition factor and weightlength relationships: History, meta-analysis and recommendations. Journal of Applied Ichthyology 22 (4): 241-253. DOI: $10.1111 /$ j.1439-0426.2006.00805.x

Froese R., Tsikliras A.C., Stergiou K.I. 2011. Editorial note on weight-length relations of fishes. Acta Ichthyologica et Piscatoria 41 (4): 261-263. DOI: 10.3750/AIP2011.41.4.01

García-Salgado M., Camarena T., Gold B.G., Vasquez M., Galland G., Nava M.G., Alarcón D.G., Ceja M.V. 2006. Línea base del estado del Sistema Arrecifal Mesoamericano: Resultados del Monitoreo Sinóptico 2004 y 2005. Vol. 1. Documento Técnico del SAM No. 18. Belize City, Belize. 
Gardner P.G., Frazer T.K., Jacoby C.A., Yanong R.P.E. 2015. Reproductive biology of invasive lionfish (Pterois spp.). Frontiers in Marine Science 2: Article 7. DOI: $10.3389 /$ fmars.2015.00007

Giacalone V.M., D’Anna G., Badalamenti F., Pipitone C. 2010. Weight-length relationships and condition factor trends for thirty-eight fish species in trawled and untrawled areas off the coast of northern Sicily (central Mediterranean Sea). Journal of Applied Ichthyology 26 (6): 954-957.

DOI: $10.1111 / \mathrm{j} .1439-0426.2010 .01491 . x$

González-Salas C., Núñez-Lara E., Ruiz-Zárate M.A., Hernández-Landa R.C., Arias-González J.E. 2003. Condition of coral reef ecosystems in central-southern Quintana Roo (Part 3: Juvenile reef fishes). Atoll Research Bulletin 496 (33): 598-610.

Gonçalves J.M.S., Bentes L., Lino P.G., Ribeiro J., Canário A.V.M., Erzini K. 1997. Weight-length relationships for selected fish species of the smallscale fisheries of the south and south-west coast of Portugal. Fisheries Research 30 (3): 253-256.

DOI: 10.1016/S0165-7836(96)00569-3

Green S.J., Akins J.L., Côté I.M. 2011. Foraging behaviour and prey consumption in the Indo-Pacific lionfish on Bahamian coral reefs. Marine Ecology Progress Series 433: 159-167.

DOI: $10.3354 /$ meps09208

Hackerott S., Valdivia A., Green S.J., Côté I.M., Cox C.E., Akins L., Layman C.A., Precht W.F., Bruno J.F. 2013. Native predators do not influence invasion success of Pacific lionfish on Caribbean reefs. PLoS ONE 8 (7): e68259.

DOI: 10.1371/journal.pone.0068259

Hossain M.Y., Mosaddequr Rahman M., Ahamed F., Ahmed Z.F., Ohtomi J. 2014. Length-weight and length-length relationships and form factor of three threatened fishes from the Ganges River (NW Bangladesh). Journal of Applied Ichthyology 30 (1): 221-224.

DOI: $10.1111 /$ jai.12251

Kimmerer W., Avent S.R., Bollens S.M., Feyrer F., Grimaldo L.F., Moyle P.B., Nobriga M., Visintainer T. 2005. Variability in length-weight relationships used to estimate biomass of estuarine fish from survey data. Transactions of the American Fisheries Society 134 (2): 481-495.

DOI: $10.1577 / \mathrm{T} 04-042.1$

Klassen J.A., Gawlik D.E., Botson B.A. 2014. Lengthweight and length-length relationships for common fish and crayfish species in the Everglades, Florida, USA. Journal of Applied Ichthyology 30 (3): 564-566. DOI: $10.1111 /$ jai.12406

Le Cren E.D. 1951. The Length-weight relationship and seasonal cycle in gonad weight and condition in the perch (Perca fluviatilis). Journal of Animal Ecology 20 (2): 201-219.

DOI: $10.2307 / 1540$

López-Gómez M.J., Aguilar-Perera A., Perera-Chan L. 2014. Mayan diver-fishers as citizen scientists:
Detection and monitoring of the invasive red lionfish in the Parque Nacional Arrecife Alacranes, southern Gulf of Mexico. Biological Invasions 16 (7): 13511357.

DOI: $10.1007 / \mathrm{s} 10530-013-0582-0$

Morris J.A., Akins J.L. 2009. Feeding ecology of invasive lionfish (Pterois volitans) in the Bahamian archipelago. Environmental Biology of Fishes 86 (3): 389-398.

DOI: $10.1007 / \mathrm{s} 10641-009-9538-8$

Okgerman H. 2005. Seasonal variations in the lengthweight relationship and condition factor of rudd (Scardinius erythrophthalmus L.) in Sapanca Lake. International Journal of Zoological Research 1 (1): 6-10.

DOI: 10.3923/ijzr.2005.6.10

Perera-Chan L.C., Aguilar-Perera A. 2014. Lengthweight and length-length relationships of the invasive red lionfish [Pterois volitans (Linnaeus, 1758): Scorpaenidae] in the Parque Nacional Arrecife Alacranes, Southern Gulf of Mexico. Journal of Applied Ichthyology 30 (1): 202-203. DOI: $10.1111 /$ jai.12294

Petrakis G., Stergiou K.I. 1995. Weight-length relationships for 33 fish species in Greek waters. Fisheries Research 21 (3-4): 465-469. DOI: 10.1016/0165-7836(94)00294-7

Pusack T.J., Benkwitt C.E., Cure K., Kindinger T.L. 2016. Invasive red lionfish (Pterois volitans) grow faster in the Atlantic Ocean than in their native Pacific range. Environmental Biology of Fishes 99 (6): 571-579.

DOI: $10.1007 /$ s10641-016-0499-4

Rodríguez-Cortés K.D. Aguilar-Perera A., BonillaGómez J.L. 2015. Growth and mortality of red lionfish, Pterois volitans (Actinopterygii: Scorpaeniformes: Scorpaenidae), in the Parque Nacional Arrecife Alacranes, southern Gulf of Mexico, as determined by size-frequency analysis. Acta Ichthyologica et Piscatoria 45 (2): 175-179.

DOI: 10.3750/AIP2015.45.2.07

Rypel A.L., Richter T.J. 2008. Empirical percentile standard weight equation for the blacktail redhorse. North American Journal of Fisheries Management 28 (6): 1843-1846.

DOI: $10.1577 / \mathrm{m} 07-193.1$

Sabido-Itzá M.M., Gómez-Poot J.M., Medina-Quej A., García-Rivas M.C., Hadad-López W. 2012. Dinámica poblacional del pez león (Pterois volitans) en el Parque Nacional Arrecifes de Xcalak (PNAX), Quintana Roo, Caribe Mexicano. Proceedings Gulf Caribbean Fisheries Institute No. 64: 67-74.

Sabido-Itzá M.M., Medina-Quej A., de JesúsNavarrete A., Gómez-Poot J.M., García-Rivas M.C. 2016. La estructura de tallas como evidencia del establecimiento de Pterois volitans (Scorpaeniformes: Scorpaenidae) en el sur del Caribe mexicano. Revista de Biología Tropical 64 (1): 369-378.

DOI: $10.15517 /$ rbt.v64i1.18943 
Sandel V., Martínez-Fernández D., Wangpraseurt D., Vásquez-Yeomans L., Vega-Cendejas M.E., Montero Sierra L. 2015. Ecology and management of the invasive lionfish Pterois volitans/miles complex (Perciformes: Scorpaenidae) in Southern Costa Rica. Revista de Biología Tropical 63 (1): 213-221.

DOI: $10.15517 /$ rbt.v63i1.14749

Schofield P.J. 2010. Update on geographic spread of invasive lionfishes (Pterois volitans [Linnaeus, 1758] and P. miles [Bennett, 1828]) in the Western North Atlantic Ocean, Caribbean Sea and Gulf of Mexico. Aquatic Invasions 5 (Suppl. 1): S117-S122. DOI: $10.3391 /$ ai.2010.5.S1.024

Schultz E.T. 1986. Pterois volitans and Pterois miles: two valid species. Copeia 1986 (3): 686-690. DOI: $10.2307 / 1444950$

Toledo-Hernández C., Vélez-Zuazo X., Ruiz-Diaz C.P., Patricio A.R., Mège P., Navarro M. MiguelSabat A., Betancur-R R., Papa R. 2014. Population ecology and genetics of the invasive lionfish in Puerto Rico. Aquatic Invasions 9 (2): 227-237.

DOI: 10.3391/ai.2014.9.2.12 J.L., Sosa-Cordero E. 2011. High species richness of early stages of fish in a locality of the Mesoamerican Barrier Reef System: A small-scale survey using different sampling gears. Biodiversity and Conservation 20 (11): 2379-2379. DOI: $10.1007 / \mathrm{s} 10531-011-9990-6$

Vega-Cendejas M.E., de Santillana M.H., Arceo D. 2012. Length-weight relationships for selected fish species from a coastal lagoon influenced by freshwater seeps: Yucatan peninsula, Mexico. Journal of Applied Ichthyology 28 (1): 140-142.

DOI: $10.1111 /$ j.1439-0426.2011.01875.x

Received: 10 April 2016

Accepted: 12 October 2016

Published electronically: 31 December 2016 